\title{
Bagaimana Mengembangkan Industri Fintech Syariah di Indonesia? Pendekatan Interpretive Structural Model (ISM)
}

\author{
How to Develop Sharia Fintech Industry in Indonesia? \\ Interpretive Structural Model Approach
}

\author{
Aam Slamet Rusydiana
}

SMART Indonesia, email: a msmart@gmail.com

\begin{abstract}
Fintech in Indonesia is an untapped market opportunity. As a country with the largest muslim population in the world, the prospect of Islamic fintech in Indonesia is very good. This study tries to answer the problems that occur, strategy, and stakeholders involved in developing Islamic fintech in Indonesia using the Interpretive Structural Model (ISM) approach. The core problem faced in developing the Islamic finance technology industry is the lack of policy instruments that maintain the work process of fintech and the availability of human resources for fintech. The strategy needed in the framework of developing Islamic fintech is the ability to manage and analyze data in the big data era and human resources in digital marketing. For ecosystem aspects or actors involved in developing Islamic fintech in Indonesia, important actors include government or regulators, educational institutions (universities), as well as existing industries (banks and other financial institutions).
\end{abstract}

Keywords: Interpretive Structural Model, Islamic fintech, Islamic finance

\begin{abstract}
Abstrak. Fintech di Indonesia adalah peluang pasar yang belum dimanfaatkan. Sebagai negara dengan populasi penduduk muslim terbesar di dunia, prospek fintech syariah di Indonesia sangat baik. Studi ini mencoba menjawab masalah yang terjadi, strategi, dan pemangku kepentingan yang terlibat dalam pengembangan fintech syariah di Indonesia menggunakan pendekatan Interpretive Structural Model (ISM). Masalah inti yang dihadapi dalam pengembangan industri teknologi keuangan syariah adalah kurangnya instrumen kebijakan yang menjaga proses kerja fintech dan ketersediaan sumber daya manusia untuk fintech. Strategi atau fondasi inti yang diperlukan dalam kerangka pengembangan fintech syariah adalah kemampuan untuk mengelola dan menganalisis data di era big data dan sumber daya manusia dalam pemasaran digital. Untuk aspek ekosistem atau aktor yang terlibat dalam pengembangan fintech syariah di Indonesia, aktor pentingnya, antara lain pemerintah atau regulator, lembaga pendidikan (universitas), dan juga industri yang ada (bank dan lembaga keuangan lainnya).
\end{abstract}

Kata kunci: Fintech syariah, Interpretive Structural Model, keuangan syariah

\section{PENDAHULUAN}

Industri keuangan syariah, menjadi obyek studi yang selalu menarik diteliti. Terutama jika dibandingkan dengan kondisi industri keuangan konvensional yang telah lebih dahulu eksis. Misalnya, hasil penelitian yang dilakukan oleh Nurfalah et al. (2018) yang menyatakan bahwa perbankan syariah relatif lebih stabil dibandingkan dengan perbankan konvensional dalam menghadapi guncangan, baik dari internal maupun eksternal. Hal ini menjadi temuan menarik yang perlu dibuktikan melalui berbagai riset di masa mendatang. Saat ini ekonomi Islam sedang mengalami euforia, baik di negara berkembang atau di negara maju sekalipun. Industri keuangan serta bentuk lembaga ekonomi Islam lain tumbuh di seantero jagat, mulai dari Timur Tengah, kawasan Asia, hingga negara-negara Barat, seperti Inggris (Rusydiana et al., 2009).

Saat ini, industri yang menarik dan sedang mengalami perkembangan adalah industri teknologi keuangan atau lebih dikenal dengan fintech. Riset ini akan mencoba mengelaborasi pengembangan industri fintech syariah di Indonesia. Teknologi keuangan atau fintech di Indonesia merupakan peluang pasar yang sangat potensial. Geografi yang luas, pertumbuhan kelas menengah yang cukup besar, dan penetrasi produk keuangan yang relatif kurang baik secara bersama-sama bergabung untuk menciptakan pasar yang tangguh untuk pengembangan fintech di Indonesia. Dengan hanya $36 \%$ dari 
populasi yang memiliki rekening bank, fintech di Indonesia menjanjikan layanan keuangan yang dapat diakses kepada penduduk yang tidak tersentuh perbankan (unbankable). Platform fintech di Indonesia secara umum tumbuh dengan pesat dari tahun 2015 hingga akhir 2017 (Hasan, 2018).

Sebagai negara berpenduduk muslim terbesar di dunia, prospek industri fintech syariah di Indonesia tampak sangat baik. Secara keseluruhan, fintech di Indonesia memiliki potensi besar karena dapat memberikan solusi untuk kebutuhan mendesak yang tidak dapat disediakan oleh lembaga keuangan tradisional. Selain itu, ledakan dalam penetrasi seluler (70\% penduduk menggunakan ponsel untuk mengakses web) di negara ini telah menciptakan lahan subur bagi peningkatan pesat industri fintech.

Financial technology (fintech) merupakan inovasi layanan keuangan dengan menggunakan teknologi agar masyarakat dapat dengan mudah mengakses produk dan layanan keuangan serta melemahkan barrier to entry (BI, 2016). Perkembangan fintech ini mengubah pola model bisnis keuangan saat ini dimana melemahnya barrier to entry memberikan peran bagi Fintech dalam memunculkan perilaku unregulated yang menjalankan model bisnis layaknya perusahaan atau institusi regulated (Bank Indoensia, 2016). Perkembangan fintech di dunia sudah dimulai sejak tahun 1800-an dengan munculnya telegraf dan semakin berkembang pada tahun-tahun selanjutnya khususnya pada era digital saat ini.

Sementara itu, fintech di Indonesia mulai berkembang dari tahun 2006 dengan jumlah perusahaan pada awalnya hanya empat perusahaan saja dan berkembang menjadi 16 perusahaan di tahun 2007 . Perkembangan signifikan terjadi pada tahun 2015 hingga 2016 dimana jumlah perusahaan yang menjalankan model bisnis fintech sekitar 165 perusahaan.

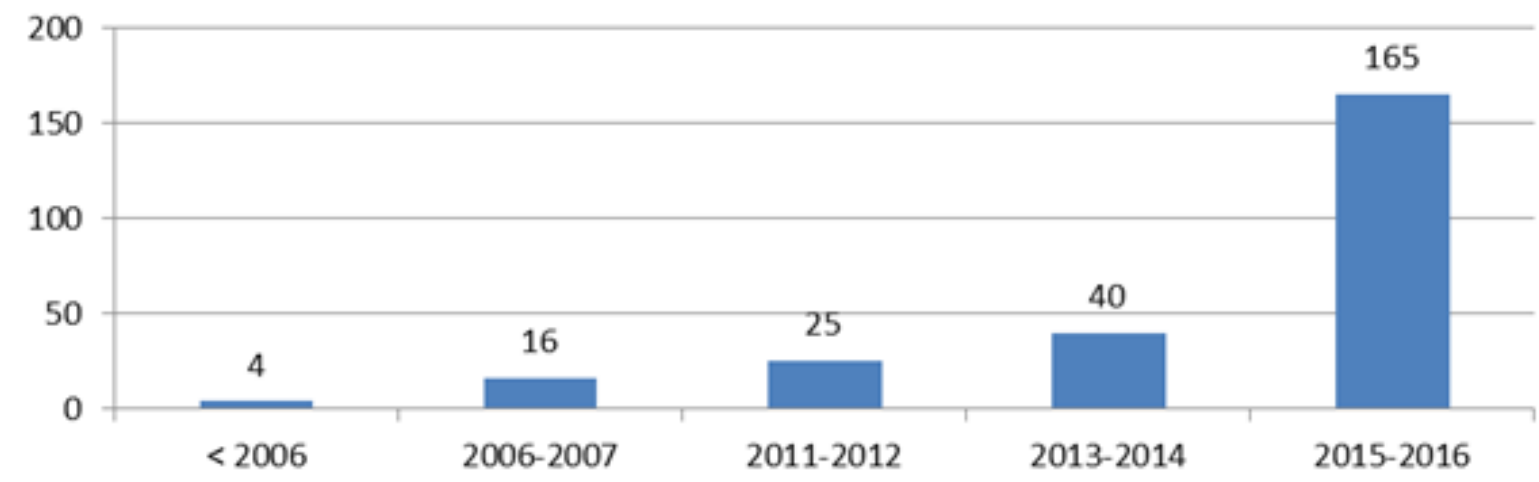

Sumber: Hadad (2017), data diolah

Gambar 1 Perkembangan jumlah perusahaan fintech di Indonesia

Berdasarkan data Otoritas Jasa Keuangan (OJK), perusahaan fintech di Indonesia terbagi kepada beberapa sektor, yaitu: 1) financial planning, 2) crowdfunding, 3) lending, 4) aggregator, 5) payment, dan 6) fintech lainnya. Hadad (2017) menerangkan bahwa perusahaan fintech di Indonesia didominasi oleh sektor pembayaran (payment) sebesar 42.22\%, sektor pinjaman (lending) 17.78\%, sektor aggregator sebesar $12.59 \%$, sektor perencanaan keuangan (financial planning) sebesar $8.15 \%$, sektor crowdfunding sebesar $8.15 \%$, dan sektor fintech lainnya sebesar $11.11 \%$.

Dalam perkembangan saat ini, industri teknologi keuangan atau yang dikenal dengan 'Fintech' memiliki berbagai jenis. Setidaknya ada empat jenis industri fintech di Indonesia: Industri fintech yang relatif besar, start-up fintech, fintech sosial, dan fintech dengan tipe 'pasar kredit'. Sebagai contoh tipe startup fintech, beberapa di antaranya adalah: Doku, iPaymu, midtrans, kartuku, dan dimo. Sementara itu, tipe fintech yang sudah relatif berukuran besar, antara lain Amartha, crowdo, investree, dan koinWorks. Tipe fintech social dapat kita temukan, seperti kitaBisa, gandengTangan, dan wujudkan. Adapun tipe industri fintech dengan pasar kredit pinjaman, yaitu bareksa, infovesta, stockbit, indoPremier, indoGold, dan olahdana. 
OJK sebagai regulator industri keuangan telah mengeluarkan legal standing untuk industri fintech. Payung hukumnya adalah dalam bentuk Peraturan OJK Nomor 77/POJK.01/2016 tentang Layanan Pinjaman Kepemilikan Peer-to-Peer Lending/P2P Lending yang diterbitkan pada akhir Desember 2016. Namun, peraturan tersebut hanya mengatur fintech dengan sistem konvensional dan belum mengatur sistem syariah yang saat ini juga mulai tumbuh.

Penelitian ini akan mencoba menjawab beberapa pertanyaan penelitian sebagai berikut: Pertama, apa sajakah masalah-masalah yang dihadapi dalam kerangka pengembangan industri fintech syariah di Indonesia? Kedua, apa strategi atau dasar pijakan penting dan krusial dalam pengembangan industri fintech syariah? Selanjutnya, siapakah sajakah pemangku kepentingan yang berperan dalam pengembangan fintech syariah di Indonesia? Melalui riset dengan metode Interpretive Structural Model (ISM), beberapa pertanyaan tersebut akan coba dijawab.

\section{TINJAUAN PUSTAKA}

KPMG mendefinisikan fintech sebagai bisnis berbasis teknologi yang bersaing atau berkolaborasi dengan lembaga keuangan (Pollari, 2016). Dalam definisi lain, Chuen dan Teo (2015) menyatakan bahwa fintech mengacu pada layanan keuangan atau produk inovatif yang disampaikan melalui teknologi baru. Dari definisi ini, fintech syariah berarti bisnis berbasis teknologi dengan layanan keuangan inovatif atau produk yang menggunakan skema syariah. Fintech syariah mempromosikan keuangan yang bertanggung jawab, etis, dan memberikan peluang untuk memengaruhi semua bentuk keuangan secara global.

Perusahaan fintech dapat diklasifikasikan sebagai: a) teknologi informasi dan perusahaan perangkat lunak yang mendukung dan memfasilitasi perusahaan sektor keuangan atau lebih disebut sebagai penyedia layanan teknologi bank dan b) tech-startups atau perusahaan inovatif kecil yang menggantikan perantara keuangan biasa, dengan kemudahan aksesibilitas yang mampu menyebabkan 'gangguan' bagi bank umum dan sistem perbankan.

Harrison et al. (2014) menunjukkan bahwa inovasi bisnis menstimulasi perkembangan ekonomi, baik pada tingkat mikro dan makro. Penerapan teknologi informasi dalam industri keuangan adalah sebuah bidang dengan potensi besar untuk inovasi. Oleh karena itu, baik perusahaan maupun investor sangat tertarik dengannya.

Webster dan Pizalla (2015) menunjukkan bahwa persaingan antara fintech dan layanan perbankan tradisional relatif semakin intens setiap tahun karena terus berkembangnya teknologi informasi. Secara bersamaan, fintech meningkatkan minat dalam layanan keuangan modern dari lembaga keuangan progresif yang bertujuan untuk mempertahankan dan memperkuat peran utama mereka di lapangan. Fintech juga mampu memberikan layanan modern berkualitas tinggi dalam bentuk yang nyaman dan efektif untuk klien mereka di manapun, dan kapanpun. Belakangan, kolaborasi antara lembaga keuangan tradisional dan fintech relatif berkembang karena kedua pihak melihat jalan yang menjanjikan untuk pengembangan lebih lanjut.

Penelitian terkait industri teknologi keuangan kaitannya dengan keuangan dan perbankan syariah telah dilakukan beberapa pihak. Misalnya penelitian yang dilakukan oleh Todorof (2018) dan CIBAFI (2018), demikian juga hasil riset dalam Global Islamic Finance Report (2017). Todorof (2018) menjelaskan bahwa keuangan Islam saat ini relatif tertinggal dalam jumlah total pelanggan dan tingkat kecanggihan produk yang tersedia dalam portofolionya. Teknologi adalah sesuatu yang dianggap memiliki efek positif pada perbankan, termasuk perbankan syariah. Dalam contoh yang terakhir, teknologi dapat diandalkan untuk mencapai keselarasan yang lebih besar dengan instrumen dan produk keuangan syariah, lebih khusus yang dianggap patuh atau sesuai dengan prinsip syariah.

Fintech dalam keuangan syariah global saat ini lebih didominasi dalam bentuk platform crowdfunding. Sebagai contoh adalah HalalSky dan LaunchGood (USA), The Ethical Crowd dan 
Yielders (UK), Pitchin dan Waqf World (Malaysia), serta EthisCrowd dan KapitalBoost (Singapura). Selain crowdfunding, tipe fintech syariah lain adalah platform akun investasi atau lebih dikenal IAP (Investment Account Platform) dan Islamic Robo-Advisor (GIFR, 2017). Salah satu isu utama dalam tema fintech syariah, baik di Indonesia maupun di area global adalah kerangka peran dan supervisi dari para pakar syariah terkait kesesuaian syariah atas industri fintech. Tata kelola konsep syariah dalam aplikasi fintech memang harus secara jelas dimuat dan dipahami para pemangku kepentingan yang berkepentingan.

Sesuai dengan penelitian yang dilakukan CIBAFI (2018), saat ini ada dua isu utama dalam pengembangan industri keuangan syariah global dan lebih khusus di Asia Tenggara. Kedua isu tersebut adalah terkait ketidakpastian dalam ekonomi global dan kebangkitan fintech serta terkait pengembangan sumber daya manusia dalam industri keuangan syariah.

Berdasarkan studi literatur dan wawancara mendalam, riset terkait pengembangan fintech syariah dengan kerangka metode ISM ini dapat dibagi ke dalam empat kriteria: (1) perspektif atau fungsi fintech secara umum, (2) masalah yang dihadapi dalam pengembangan industri fintech syariah, (3) strategi yang diperlukan dalam kerangka pengembangan fintech syariah, dan (4) ekosistem atau aktor yang berperan dalam pengembangan industri fintech syariah di Indonesia.

Dalam kriteria fungsi dan peran fintech, hari ini, beberapa fungsi industri fintech secara umum, antara lain transaksi keuangan daring, uang elektronik, akun virtual, agregator, lembaga pinjaman, crowdfunding, dan perencana keuangan personal (Saksonova \& Merlino, 2017).

Sementara itu, dari aspek masalah dan tantangan yang dihadapi dalam pengembangan industri fintech syariah, beberapa di antaranya adalah kurangnya instrumen kebijakan yang menjaga proses kerja fintech dari hulu ke hilir (Pollari, 2016), ketersediaan sumber daya manusia untuk fintech, risiko keamanan tinggi dari serangan malware (Saksonova \& Merlino, 2017), kepastian hukum dari pinjaman berbasis daring, kurang menjangkau konsumen kelas bawah, kurangnya pemahaman tentang syariah, dan kebutuhan untuk perbaikan dalam aspek tata kelola, akuntansi, dan audit syariah.

Dari aspek strategi yang diperlukan dalam kerangka pengembangan fintech syariah, khususnya di Indonesia, beberapa di antaranya adalah kemampuan mengelola dan menganalisis data di era big data, peningkatan infrastruktur teknologi, menciptakan sistem transaksi dengan mudah, pemasaran berbasis konten dalam hal pemasaran digital, menetapkan kerja sama, kolaborasi, dan investasi dengan pemangku kepentingan yang relevan, dan inovasi produk fintech (Saksonova \& Merlino, 2017).

Adapun dari aspek ekosistem atau aktor yang berperan dan berkaitan dengan pengembangan industri fintech syariah di Indonesia adalah pemerintah atau regulasi, industri fintech syariah, industri eksisting (bank dan lembaga keuangan), venture capital, lembaga pendidikan dan penelitian, penyedia jaringan internet, dan DPS-DSN MUI.

\section{METODE}

Interpretative Structural Modeling (ISM) merupakan teknik pemodelan yang dikembangkan untuk perencanaan kebijakan strategi (Marimin, 2004). ISM diciptakan pertama kali oleh J. Warfield pada tahun 1973, dimana Warfield mendefinisikan ISM sebagai proses belajar dengan bantuan komputer yang memungkinkan individu-individu atau kelompok untuk mengembangkan peta hubungan yang kompleks antara berbagai elemen yang terlibat dalam situasi yang kompleks (Warfield, 1974). ISM adalah sebuah metode perencanaan yang canggih yang digunakan untuk mengidentifikasi dan menyimpulkan aneka macam hubungan antarfaktor dalam sebuah permasalahan atau isu tertentu (Sage, 1977).

Interpretive Structural Modelling (ISM) sebagaimana diaplikasikan oleh Bhattacharya dan Momaya (2009), adalah metode perencanaan interaktif canggih yang memungkinkan sekelompok orang, 
bekerja sebagai tim, untuk mengembangkan struktur yang mendefinisikan hubungan di antara unsurunsur dalam suatu himpunan. Struktur diperoleh dengan menjawab pertanyaan sederhana. Unsur yang akan terstruktur (seperti tujuan, hambatan, masalah, dan sebagainya) yang ditentukan oleh kelompok pada awal sesi perencanaan ISM. Proses ISM dimulai dari permodelan sistem dan diakhiri dengan validasi model. Melalui teknik ISM, model mental yang tidak jelas ditransformasikan menjadi model sistem yang tampak (visible).

ISM merupakan metode dalam pengambilan keputusan dari situasi yang kompleks dengan menghubungkan dan mengorganisasi ide dalam peta visual. ISM adalah pemodelan yang menggambarkan hubungan spesifik antarvariabel, struktur menyeluruh, dan memiliki keluaran berupa model grafis berupa kuadran dan level variabel (Li \& Yang, 2014). Dalam hal pengambilan keputusan, ISM ada sedikit kesamaan dengan metode Analytic Network Process (ANP) yang dikembangkan Thomas L. Saaty. Ide dasarnya adalah menggunakan ahli yang berpengalaman dan pengetahuan praktis untuk menguraikan sistem yang rumit menjadi beberapa subsistem (elemen) dan membangun sebuah model struktural bertingkat. ISM sering digunakan untuk memberikan pemahaman dasar situasi yang kompleks, serta menyusun tindakan untuk memecahkan masalah (Gorvett \& Liu, 2007). Metode ISM banyak diaplikasikan dalam riset manajemen strategis pada berbagai bidang. Dalam riset ekonomi keuangan, Devi dan Rusydiana (2016) mencoba meneliti terkait strategi pengembangan model pinjaman berbasis kelompok di Indonesia.

Tabel 1 Keterkaitan antarsub-elemen pada teknik ISM

\begin{tabular}{|c|c|c|}
\hline & Jenis & Interprestasi \\
\hline 1. & Pembandingan (comparative) & . A lebih penting/besar/indah, daripada $\mathrm{B}$ \\
\hline 2. & Pernyataan (definitive) & $\begin{array}{l}\text { - A adalah atribut B } \\
\text {. A termasuk di dalam B } \\
\text {. A mengartikan B }\end{array}$ \\
\hline 3. & Pengaruh (influence) & $\begin{array}{l}\text {. A menyebabkan B } \\
\text {. A adalah sebagai penyebab B } \\
\text {. A mengembangkan B } \\
\text {. A menggerakkan B } \\
\text {. A meningkatkan B }\end{array}$ \\
\hline 4. & Ruang (spiral) & $\begin{array}{l}\text { - A adalah selatan/utara B } \\
\text {. A di atas B } \\
\text {. A sebelah kiri B }\end{array}$ \\
\hline 5. & Waktu (temporate/time scale) & $\begin{array}{l}\text { A mendahului } \mathrm{B} \\
\text {. A mengikuti } \mathrm{B} \\
\text {. A mempunyai prioritas lebih dari B }\end{array}$ \\
\hline
\end{tabular}

Langkah pertama dalam pengolahan ISM adalah membuat Structural Self Interaction Matrix (SSIM), dimana variabel-variabel tersebut dibuat hubungan konstektualnya dengan menjadikan satu variabel $i$ dan variabel $j$. Selanjutnya adalah membuat Reachibility Matrix (RM) dengan mengubah V, A, X, dan O dengan bilangan 1 dan 0. Langkah terakhir adalah membuat Canonical Matrix untuk menentukan level melalui iterasi. Setelah tidak ada lagi irisan (intersection), selanjutnya dibuat model yang dihasilkan oleh ISM yang merupakan suatu model untuk memecahkan masalah, dalam hal ini pengembangan fintech syariah. Dari model tersebut kemudian nantinya akan dibuat suatu road map pengembangan lembaga (level).

Menurut Marimin (2004) proses metode ISM dilakukan perhitungan menurut Aturan Transivitas, dimana dilakukan koreksi terhadap SSIM sampai terjadi matriks yang tertutup. Modifikasi SSIM membutuhkan masukan dari para panelis/pakar, dengan diberi catatan khusus agar perhatian ditunjukan hanya pada subelemen tertentu. Hasil revisi SSIM dan matriks yang memenuhi syarat Aturan Transivitas diproses lebih lanjut. Untuk revisi dapat juga dilakukan transformasi matriks 
dengan program komputer. Aturan Transivitas merupakan aturan kelengkapan dari lingkaran sebab akibat (casual-loop).

Pengolahan lebih lanjut dari RM yang telah memenuhi Aturan Transivitas adalah penetapan pilihan jenjang (level partition). Pengolahan bersifat tabulatif dengan pengisian format dan bisa dibantu dengan komputer. Berdasarkan pilihan jenjang maka dapat digambarkan skema setiap elemen menurut jenjang vertikal maupun horizontal. Untuk beragam subelemen dalam suatu elemen berdasarkan RM disusunlah Driver-Power-Dependence. Klasifikasi subelemen dipaparkan dalam empat sektor berikut (Marimin, 2004):

a Sektor 1: Weak driver-weak dependent variables (autonomous). Perubahan di sektor ini umumnya tidak berkaitan dengan sistem dan mungkin memiliki hubungan kecil, meskipun hubungan bisa saja kuat.

b Sektor 2: Weak driver-strongly dependent variables (dependent). Umumnya perubahan di sector ini tidak bebas.

c Sektor 3: Strong driver-strongly dependent variables (linkage). Variabel pada sektor ini harus dikaji secara hati-hati sebab hubungan antarvariabel tidak stabil. Setiap tindakan pada variabel tersebut akan memberikan dampak terhadap lainnya dan umpan balik pengaruhnya bisa memperbesar dampak.

d Sektor 4: Strong drive weak dependent variables (independent). Variabel pada sektor ini merupakan bagian sisa dari sistem dan disebut variabel bebas.

Ada beberapa studi terkait ekonomi dan keuangan Islam yang telah dilakukan dengan menggunakan metode ISM. Beberapa di antaranya dilakukan oleh Rusydiana dan Devi (2018) tentang koperasi syariah, Ascarya et al. (2012) tentang pengembangan bank syariah, dan Devi dan Rusydiana (2016) pada model peminjaman berbasis kelompok. Sementara Bolanos et al. (2005) dan Kanungo dan Batnagar (2002) untuk aplikasi industri lainnya. Penelitian menggunakan metode ISM dengan lebih teoritis telah dilakukan oleh Lee (2007) dan Thakkar et al. (2007).

\section{HASIL DAN PEMBAHASAN}

Berdasarkan identifikasi masalah, strategi, dan hal-hal yang berkaitan dengan pengembangan industri fintech di Indonesia, kemudian dibangunlah model kerangka ISM untuk beberapa tujuan yang diinginkan. Dalam hal ini adalah terkait aspek masalah atau tantangan yang dihadapi, strategi pengembangan, dan para pemangku kepentingan yang terlibat dalam pengembangan industri fintech syariah di Indonesia. Untuk membangun hubungan kontekstual antarvariabel dalam model, metode ISM menggunakan opini dari para pakar dengan kerangka VAXO. Kaitannya dengan penelitian ini adalah sekelompok grup pakar dilibatkan dalam menyusun model yang terdiri dari akademisi dan praktisi fintech.

Untuk membangun sebuah model, peneliti memutuskan untuk mengikuti metode tradisional yang lazim digunakan melalui brainstorming serta wawancara mendalam atau indepth interview dengan para pakar, untuk menerima masukan dan merevisi model secara berkala. Beberapa literatur dan studi terkait pengembangan industri fintech juga didiskusikan dengan para pakar untuk memvalidasi dan membuat sempurna model.

Untuk menganalisis hubungan antarvariabel atau antar-enabler dari pengembangan fintech syariah dari masing-masing kelompok tujuan, hubungan kontekstual dipilih dengan mendefinisikan pengaruh satu variabel terhadap variabel lain: apakah memengaruhi, dipengaruhi, saling memengaruhi, atau tidak ada hubungan sama sekali. Dari dasar ini, hubungan konstekstual antarvariabel dibangun. Para pakar diminta justifikasi dalam format kuesioner untuk membandingkan pernyataan dalam kolom dengan baris untuk masing-masing kotak pertanyaan dengan memilih nilai antara $\mathrm{V}, \mathrm{A}, \mathrm{X}$, atau $\mathrm{O}$, untuk merepresentasikan persepsi mereka atas hubungan antara variabel tersebut. 


\section{Structural Self Interaction Matrix (SSIM)}

Tampak dalam Tabel 2, terdapat tujuh variabel terkait aktor yang berperan dalam pengembangan fintech syariah di Indonesia yang disusun dalam format baris dan kolom. Variabel dalam baris dan kolom direpresentasikan masing-masing dengan huruf $i$ dan $j$. Dengan demikian, setiap pasangan variabel dianalisis secara terpisah setelah pembentukan grid, yang diperoleh dalam proses di atas. Empat kata kunci digunakan untuk mewakili arah hubungan antara satu set variabel ( $i$ dan $j$ ), dimana:

a. V mengindikasikan bahwa variabel $i$ memengaruhi variabel $j$.

b. A mengindikasikan bahwa variabel $j$ memengaruhi variabel $i$.

c. X mengindikasikan bahwa variabel $i$ memengaruhi variabel $j$ dan sebaliknya variabel $j$ memengaruhi variabel $i$, atau dengan arti lain terdapat hubungan saling memengaruhi antara variabel $i$ dan $j$.

d. O mengindikasikan bahwa variabel $i$ dan $j$ tidak saling berhubungan.

Hubungan antarvariabel dalam model direpresentasikan dalam sebuah matriks yang disebut sebagai structural self interaction matrix (SSIM), dengan nilai untuk setiap pasangan variabel menjadi nilai yang disepakati di antara para pakar.

Tabel 2 Structural self interaction matrix (SSIM)

\begin{tabular}{lllllllll}
\hline No & \multicolumn{1}{c}{ Deskripsi Variabel } & 7 & 6 & 5 & 4 & 3 & 2 & 1 \\
\hline A1 & Pemerintah/regulator & V & X & O & O & V & A & \\
A2 & Industri fintech syariah & O & V & A & V & O & & \\
A3 & Industri eksisting (lembaga keuangan/bank) & V & A & X & O & & & \\
A4 & Perusahaan modal ventura & A & A & X & & & & \\
A5 & Universitas & X & V & & & & & \\
A6 & Penyedia jaringan internet & V & & & & & & \\
A7 & DPS-DSN MUI & & & & & & & \\
\hline
\end{tabular}

Ket.: Entri dalam tabel: V ketika baris memengaruhi kolom; A ketika kolom memengaruhi baris; X ketika baris dan kolom saling memengaruhi; dan O ketika tidak ada hubungan antara baris dan kolom.

\section{Reachibility Matrix}

Reachibility Matrix (RM) diperoleh dari structural self interaction matrix (SSIM) dengan menggunakan proses dua langkah. Pada langkah pertama, abjad yang digunakan untuk menunjukkan hubungan antarvariabel dalam SSIM diganti dengan "0" atau "1". Nilai dalam RM tergantung pada jenis hubungan dalam SSIM (Faisal, 2015) dan dirangkum dalam hubungan berikut ini:

1 Jika hubungan antara variabel dalam satu baris dengan variabel lain dalam kolom adalah "V", maka dalam RM awal, entri baris menjadi "1", sementara entri kolom antara dua variabel ini menjadi "0";

2 Jika hubungan antara variabel dalam satu baris dengan variabel lain dalam kolom adalah "A", maka dalam RM awal, entri baris menjadi "0", sementara entri kolom antara dua variabel ini menjadi "1";

3 Jika hubungan antara variabel dalam satu baris dengan variabel lain dalam kolom adalah "X", maka dalam RM awal, entri baris menjadi "1", sementara entri kolom antara dua variabel ini menjadi "1";

4 Jika hubungan antara variabel dalam satu baris dengan variabel lain dalam kolom adalah "O", maka dalam RM awal, entri baris menjadi "0", sementara entri kolom antara dua variabel ini menjadi "0".

Berdasarkan aturan di atas, RM awal untuk enabler strategi pengembangan industri fintech syariah dibangun. Selanjutnya, dengan memasukkan konsep transitivitas (Ravi, 2015), RM akhir diperoleh. Transitivitas dalam hubungan kontekstual adalah asumsi dasar yang dibuat dalam ISM. Konsep ini menyatakan bahwa jika variabel $\mathrm{X}$ terkait dengan $\mathrm{Y}$ dan $\mathrm{Y}$ terkait dengan $\mathrm{Z}$, maka $\mathrm{X}$ harus terkait dengan Z (Venkatesh et al., 2015; Jabeen et al., 2017). RM juga menyediakan driving power dan 
dependence power dari setiap enabler. Dengan demikian, dalam tabel RM terakhir (Tabel 3), kekuatan memengaruhi untuk A1 (pemerintah atau regulator) adalah jumlah total nilai-nilai entri dalam baris, yaitu 7. Sementara itu, nilai dependence power untuk A1 (jumlah dari entri dalam kolom) adalah 4. Demikian pula, nilai-nilai driving power dan dependence power dihitung untuk semua enabler yang tersisa.

Tabel 3 Final Reachibility Matrix (RM)

\begin{tabular}{lllllllllc}
\hline No & \multicolumn{1}{c}{ Deskripsi Variabel } & 1 & 2 & 3 & 4 & 5 & 6 & 7 & $\begin{array}{c}\text { Driving } \\
\text { power }\end{array}$ \\
\hline A1 & Pemerintah/regulator & 1 & 1 & 1 & 1 & 1 & 1 & 1 & 7 \\
A2 & Industri fintech syariah & 1 & 1 & 1 & 1 & 1 & 1 & 1 & 7 \\
A3 & Industri eksisting (lembaga keuangan/bank) & 1 & 1 & 1 & 1 & 1 & 1 & 1 & 7 \\
A4 & Perusahaan modal ventura & 0 & 0 & 0 & 1 & 0 & 1 & 0 & \\
A5 & Universitas & 1 & 1 & 1 & 1 & 1 & 1 & 1 & 7 \\
A6 & Penyedia jaringan internet & 0 & 0 & 0 & 0 & 0 & 1 & 0 & 1 \\
A7 & DPS-DSN MUI & 0 & 0 & 0 & 0 & 0 & 1 & 1 & 2 \\
\hline & Dependence Power & 4 & 4 & 4 & 5 & 4 & 7 & 5 & \\
\hline
\end{tabular}

Dari RM akhir, langkah selanjutnya adalah membangun reachibility set dan antecedent set. Jangkauan yang ditetapkan untuk enabler tertentu terdiri dari enabler itu sendiri dan enabler lain yang dapat membantu mencapainya. Demikian pula, set anteseden terdiri dari enabler itu sendiri dan enabler lain yang memengaruhinya. Perpotongan set ini diturunkan untuk semua enabler. Enabler yang mana antecedent set dan reachibility set adalah sama, membentuk level teratas dari hierarki dalam model ISM. Enabler ini tidak akan membantu mencapai enabler lain di atas tingkat mereka (Jabeen \& Faisal, 2018). Tingkat yang diidentifikasi membantu dalam membangun kuadran dan model akhir ISM.

\section{Analisis Kuadran MICMAC}

Dalam penelitiannya, Godet (1986) telah mempopulerkan matriks perkalian dampak silang atau matrix of cross impact multiplications applied to classification (MICMAC) untuk mengklasifikasikan variabel sistem yang diteliti. Dasar dari klasifikasi ini adalah driving power dan dependence power yang dihitung dalam RM akhir. Selain itu, analisis MICMAC dapat digunakan untuk memeriksa hubungan langsung dan laten di antara enabler yang diperoleh dari teknik ISM. Jadi, berdasarkan driving power dan dependence power, enabler dalam penelitian ini diklasifikasikan ke dalam empat kelompok, seperti yang ditunjukkan dan dijelaskan berikut ini:

1 Variabel Autonomous: Variabel-variabel ini tidak memiliki daya pengaruh yang tinggi atau ketergantungan yang tinggi. Mereka terlepas dari sistem, dimana mereka memiliki beberapa tautan yang mungkin sangat kuat. Kuadran I mewakili variabel otonom (autonomous). Dalam penelitian ini, tidak ada enabler yang masuk dalam kategori ini.

2 Variabel Dependent: Kuadran II merupakan variabel dependen yang memiliki kekuatan memengaruhi rendah dan ketergantungan tinggi. Dari analisis MICMAC, enabler 4, 6 dan 7 adalah variabel dependen.

3 Variabel Linkage: Variabel-variabel ini memiliki daya pengaruh yang tinggi sekaligus ketergantungan yang tinggi pula. Karakteristiknya adalah bahwa setiap tindakan pada mereka akan memiliki efek pada variabel di atas tingkat mereka dan efek umpan balik pada diri mereka sendiri. Kuadran III merupakan variabel linkage. Dalam penelitian ini, enabler 1, 2, 3 dan 5 termasuk dalam kategori variabel linkage.

4 Variabel Independent: Variabel-variabel ini memiliki daya memengaruhi yang tinggi dan ketergantungan yang rendah. Mereka mewakili Kuadran IV. tidak ada enabler yang masuk dalam kategori ini. 


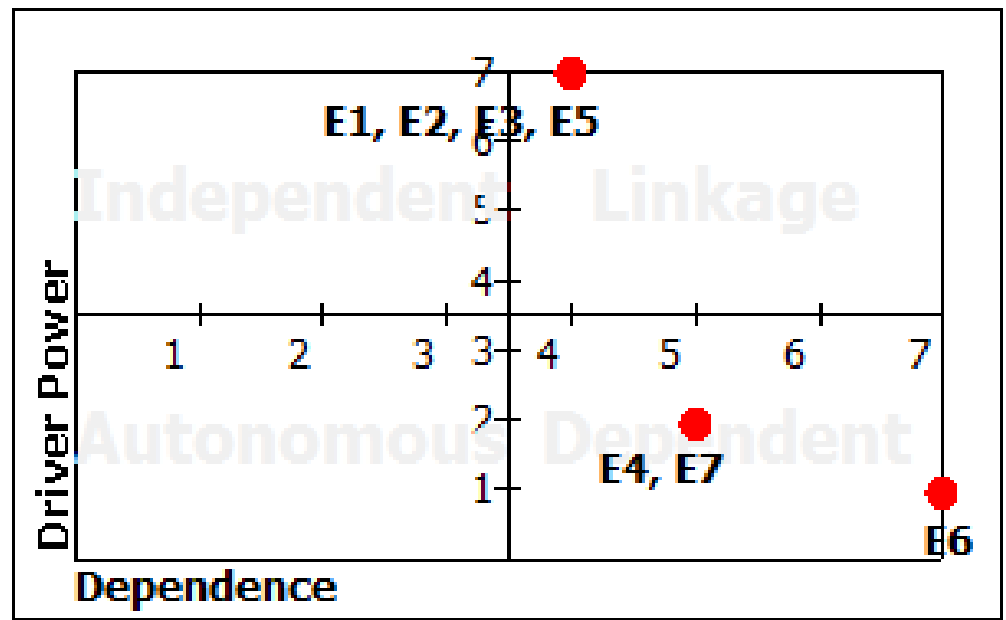

Gambar 2 Analisis kuadran MICMAC pada masalah pengembangan fintech syariah

\section{Diskusi}

Gambar 3 menunjukkan level dari masalah dan tantangan pada pengembangan industri fintech syariah di Indonesia. Masalah pentingnya, antara lain kurangnya instrumen kebijakan yang menjaga proses kerja fintech dari hulu ke hilir (E1), ketersediaan SDM untuk fintech (E2), risiko keamanan tinggi dari serangan malware (E3), dan kurang menjangkau konsumen kelas bawah (E5) (Level 3). Tantangan pengembangan industri fintech syariah di Indonesia selanjutnya adalah kepastian hukum dari pinjaman berbasis daring (E4) dan kebutuhan untuk perbaikan dalam aspek tata kelola, akuntansi, dan audit syariah (E7) (Level 2). Tantangan terakhir namun tidak kalah penting adalah kurangnya pemahaman praktisi tentang syariah (E6) (Level 1).

Dalam Peraturan OJK Nomor 77/POJK.01/2016 tentang Layanan Pinjaman Berbasis Teknologi Langsung, konsep fintech syariah tidak termasuk dalam regulasi yang disebutkan. Demikian pula, beleid yang sedang disusun oleh OJK, di mana konsep syariah tidak terkandung di dalamnya. OJK menjelaskan bahwa aturan yang disusun adalah payung hukum. Hal itu berarti bahwa peraturan itu mengatur perusahaan fintech secara umum. Namun, ada kemungkinan bahwa pihak berwenang akan mengeluarkan peraturan khusus (terkait fintech syariah) dalam waktu dekat. Apalagi, pasar jasa keuangan berbasis syariah cukup populer di masyarakat saat ini. Terkait SDM yang menjadi tantangan kedua, hal ini sering kali menjadi masalah umum yang dihadapi industri lain sekalipun. Misalnya di dunia perbankan syariah (Rusydiana, 2016) dan keuangan mikro, masalah SDM adalah hal krusial yang perlu dicari solusinya. Demikian pula yang terjadi pada industri keuangan syariah lain (Rusydiana \& Devi, 2017).

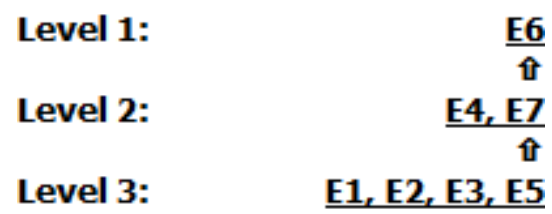

Gambar 3 Level masalah industri fintech syariah

Dari aspek strategi yang diperlukan dalam kerangka pengembangan industri fintech syariah khususnya di Indonesia, strategi yang dianggap penting adalah (a) kemampuan mengelola dan menganalisis data di era big data (Level 5). Strategi penting selanjutnya adalah (e) SDMa dari sisi pemasaran digital (Level 4) diikuti oleh (c) menciptakan sistem transaksi dengan mudah (Level 3). Pemasaran berbasis konten dalam hal pemasaran digital dan $(\mathrm{g})$ inovasi produk fintech menjadi strategi yang perlu dilakukan selanjutnya. Terakhir dan tidak kalah penting adalah (b) peningkatan infrastruktur teknologi dan (f) kerja sama, kolaborasi, dan investasi dengan pemangku kepentingan yang relevan. 
Saksonova dan Merlino (2017) mengatakan bahwa kemampuan mengelola dan menganalisis data di era big data adalah syarat mutlak dalam pengembangan industri berbasis teknologi di manapun. Bahkan, semakin canggih infrastruktur dan kondisi di sebuah negara, kemampuan para analisis semakin perlu kualitas yang tinggi. Karena hal itu adalah prasyarat keberhasilan pengembangan industri fintech secara umum, termasuk fintech syariah. Seperti halnya di negara maju lain, kemampuan mengelola dan menganalisis data di era big data menjadi variabel penting dalam strategi pengembangan fintech syariah di Indonesia.

Adapun dari aspek ekosistem atau aktor yang berperan dan berkaitan dengan pengembangan industri fintech syariah di Indonesia, pemangku kepentingan terpenting adalah pemerintah atau regulasi (A1) dan lembaga pendidikan dan penelitian (A5). Aktor selanjutnya adalah industri eksisting (bank dan lembaga keuangan) (A3), venture capital (A4), dan penyedia jaringan internet (A6). DPS-DSN MUI (A7) juga memiliki peran yang tidak kalah penting dalam pengembangan industri fintech syariah, khususnya dari sisi pengembangan aturan hukum terkait produk. Keseluruhan aktor ini kemudian akan memengaruhi perkembangan industri fintech syariah (A2) secara umum di masa yang akan datang.

Seperti kita ketahui, pemerintah secara signifikan memengaruhi perkembangan industri keuangan syariah secara umum. Begitu pula industri fintech. Dalam hal ini, regulasi yang memberikan dukungan akan diharapkan membantu memfasilitasi pengembangan industri fintech syariah di masa depan.

\section{SIMPULAN}

Perkembangan digital menjadi kesempatan bagi semua industri termasuk industri keuangan, khususnya industri keuangan syariah untuk merevolusi kegiatan konvensional menjadi sebuah inovasi layanan dan produk digital yang dapat memudahkan masyarakat dalam mengaksesnya. Namun jika perkembangan digital ini tidak dimanfaatkan, maka akan menjadi ancaman bagi industri keuangan secara keseluruhan karena banyak bermunculan perusahaan start-up yang mengembangkan layanan dan produk keuangan digital.

Secara umum, fintech di Indonesia memiliki potensi besar karena dapat memberikan solusi untuk kebutuhan mendesak yang tidak dapat diberikan oleh lembaga keuangan tradisional, khususnya fintech syariah. Berdasarkan analisis, pengembangan industri fintech syariah dengan kerangka ISM dibagi menjadi empat kriteria: (1) perspektif fungsi fintech, (2) masalah yang dihadapi dalam mengembangkan fintech syariah, (3) strategi atau dasar pijakan yang diperlukan dalam kerangka pengembangan fintech syariah, dan (4) ekosistem atau aktor yang terlibat dalam pengembangan fintech syariah di Indonesia.

Masalah inti dan tantangan yang dihadapi dalam pengembangan industri teknologi keuangan syariah adalah kurangnya instrumen kebijakan yang menjaga proses kerja fintech dan juga ketersediaan SDM untuk fintech. Strategi inti atau fondasi yang diperlukan dalam kerangka pengembangan fintech syariah adalah kemampuan untuk mengelola dan menganalisis data di era big data dan SDM dalam pemasaran digital. Untuk aspek ekosistem atau aktor yang terlibat dan terkait dalam pengembangan fintech syariah di Indonesia, aktor pentingnya adalah pemerintah atau regulator, lembaga pendidikan (universitas), dan juga industri yang ada (bank dan lembaga keuangan lainnya).

Untuk penelitian pada masa mendatang, dibutuhkan model dan kerangka yang lebih lengkap kaitannya dengan elemen dan subelemen yang lebih komprehensif dengan total sembilan elemen terkait pengembangan industri fintech syariah di Indonesia. Selain itu, diharapkan narasumber dari kalangan pakar lebih variatif dari kalangan akademisi, praktisi, dan regulator terkait. 


\section{DAFTAR PUSTAKA}

Ascarya, Widyo, G., Widodo, C., Enny, A., \& Ferry, S. (2012). Strategi Meningkatkan Preferensi Perbankan Syariah Indonesia dalam Menggunakan Pembiayaan Bagi Hasil. Jakarta, Bank Indonesia.

[BI] Bank Indonesia. (2016). Booklet Keuangan Inklusif. Jakarta, Departmen Pengembangan Akses Keuangan dan UMKM Bank Indonesia.

Bolanos, R., Fontela, E., Nenclares, A., \& Pastor, P. (2005). Using Interpretive Structural Modelling in strategic decision-making groups. Management Decision, 43(6), 877-895.

Chuen, D.L.K., \& Teo, G.S. (2015). Emergence of fintech and the LASIC principles. The Journal of Financial Perspectives: Fintech, Winter 2015, 24-37.

CIBAFI (2018). 'Evaluating future impacts: Strategic thinking, branding, and financial technologies'. Global Islamic Bankers' Survey 2018.

Devi, A. \& Rusydiana, A.S. (2016). Islamic group lending model (GLM) and financial inclusion. International Journal of Islamic Business Ethics, 1(1), 80-94.

[GIFR] Global Islamic Finance Report (2017a). 'Islamic finance in the digital age: Fintech revolution'. Global Islamic Finance Report 2017, 282-290.

[GIFR] Global Islamic Finance Report (2017b). 'Embracing fintech by sharia fraternity'. Global Islamic Finance Report 2017, 291-296.

Godet, M. (1986). Introduction to 'la prospective': Seven key ideas and one scenario method. Futures, $18(2), 134-157$.

Gorvett, R. \& Liu, N. (2007). Using Interpretive Structural Modeling to Identify and Quantify Interactive Risks. Orlando (USA), ASTIN Colloquium.

Hadad, M.D. (2017). Financial Technology (Fintech) di Indonesia. Kuliah Umum tentang Fintech, Indonesia Banking School.

Harrison, R., Jaumandreu, J., Mairesse, J., \& Peters, B. (2014). Does innovation stimulate employement? A firm level analysis using comparable micro-data from four European countries. International Journal of Industrial Organization, 35, 29-43.

Hasan, S.M. (2018). Fintech in Indonesia: An Islamic outlook", article in http://ethiscrowd.com.

Jabeen, F., \& Faisal, M.N. (2018), "Imperatives for improving entrepreneurial behavior among females in the UAE: An empirical study and structural model", Gender in Management: An International Journal, pp. 1754-2413.

Jabeen, F., Faisal, M.N., \& Katsioloudes, M.I. (2017). Entrepreneurial mindset and the role of universities as strategic drivers of entrepreneurship evidence from the UAE. Journal of Small Business and Enterprise Development, 24(1), 136-157.

Kanungo, S. \& Batnagar, V.V. (2002). Beyond generic models for information system quality: The use of Interpretative Structural Modelling (ISM). Journal of System Research and Behavior Science, 19(2), 531-549.

Lee, D.M. (2007). Structured Decision Making with Interpretive Structural Modelling (ISM). Canada, Sorach Inc.

Li, M. \& Yang, J. (2014). Analysis of interrelationships between critical waste factors in office building retrofit projects using Interpretive Structural Modeling. International Journal of Construction Management, 14(1), 15-27.

Marimin (2004). Pengambilan Keputusan Kreteria Majemuk: Teknik dan Aplikasi. Jakarta, Gramedia Widiasarana Indonesia.

Nurfalah, I., Rusydiana, A.S., Laila, N., \& Cahyono, E.F. (2018). Early warning to banking crises in the dual financial system in Indonesia: The Markov Switching approach. JKAU: Islamic Economics, 31(2), 133-156.

Pollari, I. (2016). The rise of fintech: Opportunities and challenges. The Finsia Journal of Applied Finance, 3.

Rusydiana, A.S. \& Devi, A. (2018). Mengembangkan koperasi syariah di Indonesia: Pendekatan Interpretive Structural Model (ISM). Jurnal Economica, 9(1). 
Rusydiana, A.S. \& Devi, A. (2017). Analisis pengelolaan dana wakaf uang di Indonesia: Pendekatan metode Analytic Network Process (ANP). Al-Awqaf: Jurnal Wakaf dan Ekonomi Islam, 10(2), $115-133$.

Rusydiana, A.S. (2016). Analisis masalah pengembangan perbankan syariah di Indonesia: Aplikasi metode Analytic Network Process. Esensi: Jurnal Bisnis dan Manajemen, 6(2), 237-246.

Rusydiana, A.S. (2009). Ekonomi Islam Substantif. Jakarta, GP Press.

Sage, A. (1977). Interpretive Structural Modeling: Methodology for Large-Scale Systems. New York, McGraw-Hill.

Saksonova, S. \& Merlino, I.K. (2017). Fintech as financial innovation: The possibilities and problems of implementation. European Research Studies Journal, XX(3A), 961-973.

Thakkar, J., Deshmukh, S.G., Gupta, A.D., \& Shankar, R. (2006). "Development of a balanced scorecard, an integrated approach of Interpretive Sructural Modeling (ISM) and Analytic Network Process (ANP)". International Journal of Productivity and Performance Management, 56(1), 25-59.

Todorof, M. (2018). Shariah-compliant fintech in the banking industry. ERA Forum, doi:10.1007/s12027-018-0505-8.

Venkatesh, V.G., Rathi, S., \& Patwa, S. (2015). Analysis on supply chain risks in indian apparel retail chains and proposal of risk prioritization model using interpretive structural modeling. Journal of Retailing and Consumer Services, 26, 153-167.

Warfield, J.N. (1974). Developing interconnected matrices in structural modeling. IEEE Transactions on System, Man, and Cybernetics, 4(1), 81-87.

Webster, I. \& Pizalla, J. (2015). Fintech: Are banks responding appropriately?. EY Publication 2015. 